\title{
Fabrication and characterization of low cost ceramic membranes for microfiltration of Acutodesmus obliquus using modified clays
}

\author{
Fabricação e caracterização de membranas \\ cerâmicas de baixo custo para microfiltracao \\ de Acutodesmus obliquus usando \\ argilas modificadas
}

Julcelly Dayara de Oliveira Henriques ${ }^{1}$, Marina Wendt Pedrassani ${ }^{1}$, Walderson Klitzke ${ }^{2}$, Thamayne Valadares de Oliveira ${ }^{3}$, Patricia Angélica Vieira ${ }^{4}$, André Bellin Mariano ${ }^{5}$, Rafael Bruno Vieira ${ }^{1}$

\footnotetext{
${ }^{1}$ Department of Chemical Engineering, Graduate Program in Chemical Engineering, Federal University of Paraná, Curitiba, PR, Brazil.

${ }^{2}$ Department of Forest Engineering, Federal University of Paraná, Curitiba, PR, Brazil.

${ }^{3}$ Department of Chemical Engineering, Graduate Program in Chemical Engineering, Federal University of Santa Catarina, Florianopolis, SC, Brazil.

${ }^{4}$ Faculty of Chemical Engineering, Graduate Program in Chemical Engineering, Federal University of Uberlândia, Uberlândia, MG, Brazil.

${ }^{5}$ Department of Electric Engineering, Graduate Program in Materials Engineering and Science (PIPE) and Nucleus of Research and Development in Self-sustaining Energy (NPDEAS), UFPR - Federal University of Paraná, Curitiba, PR, Brazil.

e-mail: rafaelbruno@ufpr.br, julcellydayara@yahoo.com.br,marina.pedrassani@gmail.com,wklitzke@ufpr.br, andrebmariano@gmail.com, thamaynevaladares@gmail.com, patriciavieira@ufu.br
}

\begin{abstract}
Tubular ceramic microfiltration membranes were prepared by extruding thermally treated clay (TC) and raw clay (NC) mixtures in different fractions with the addition of cationic manioc starch. Previous studies have verified that membranes containing TC possess higher hydraulic permeability and permeate flow values than those containing only $\mathrm{NC}$ for application in crossflow filtration. However, TC membranes had a low mechanical strength. Therefore, this study aimed to increase the mechanical strength without adversely affecting their permeate flow and hydraulic permeability. The physical, mineralogical, and morphological characteristics of the membranes were determined. The membranes were used for microfiltration of Acutodesmus obliquus microalgae with applied pressure of 1 bar with a volumetric flow rate of $250 \mathrm{~L} / \mathrm{h}$ at a temperature of $10 \pm 5^{\circ} \mathrm{C}$. The efficiency of each ceramic membrane was evaluated in terms of the permeate flow for water and microalgae and hydraulic permeability. The mixture of $70 \% \mathrm{TC}$, $15 \%$ starch fractions and sintered at $1150^{\circ} \mathrm{C}$ exhibited optimal performance in mechanical strength $(15.1 \pm 0.2 \mathrm{MPa})$, water permeate flow of $522.4 \pm 0.3 \mathrm{Kg} \cdot \mathrm{m}^{-2} \cdot \mathrm{h}^{-1}$, microalgae permeate flow of $114.8 \pm 0.8$ $\mathrm{Kg} \cdot \mathrm{m}^{-2} \cdot \mathrm{h}^{-1}$ and hydraulic permeability of $568.0 \pm 0.3 \mathrm{Kg} \cdot \mathrm{m}^{-2} \cdot \mathrm{h}^{-1} \cdot$ bar.
\end{abstract}

Keywords: membranes, kaolinite, mechanical strength.

\section{RESUMO}

Membranas de microfiltração em cerâmica tubular foram preparadas por extrusão de misturas de argilas naturais (NC) e argilas tratadas termicamente (TC) em diferentes frações com a adição de amido de mandioca catiônico. Estudos anteriores verificaram que membranas contendo TC possuíam maior permeabilidade hidráulica e fluxo permeado do que aquelas que continham somente NC para a aplicação em filtração tangencial. Entretanto, as membranas TC tinham uma baixa resistencia mecânica. Assim sendo, este estudo teve como objetivo aumentar a resistência mecânica sem afetar adversamente seu fluxo permeado e permeabilidade hidráulica. As características físicas, mineralógicas e morfológicas das 
membranas foram determinadas. As membranas foram usadas para microfiltração de microalga Acutodesmus obliquus com pressão aplicada de 1 bar com taxa de fluxo volumétrica de $250 \mathrm{~L} / \mathrm{h}$ em uma temperatura de $10 \pm 5^{\circ} \mathrm{C}$. A eficiência de cada membrana cerâmica foi avaliada em termos de fluxo permeado para água e microalga e permeabilidade hidráulica. A mistura de $70 \%$ de TC, $15 \%$ de fração de amido e sinterizado em $1150^{\circ} \mathrm{C}$ exibiu ótimo desempenho em resistência mecânica $(15.1 \pm 0.2 \mathrm{MPa})$, fluxo permeado de água de $522.4 \pm 0.3 \mathrm{Kg} \cdot \mathrm{m}^{-2} \cdot \mathrm{h}^{-1}$, fluxo permeado de microalga de $114.8 \pm 0.8 \mathrm{Kg} \cdot \mathrm{m}^{-2} \cdot \mathrm{h}^{-1} \mathrm{e}$ permeabilidade hidráulica de $568.0 \pm 0.3 \mathrm{Kg} \cdot \mathrm{m}^{-2} \cdot \mathrm{h}^{-1} \cdot$ bar.

Palavras-chave: membranas, caulinita, resistência mecânica.

\section{INTRODUÇÃO}

Microalgae are widely used in biofuel production given their unique characteristics of high growth rate, productivity, and oil concentration, as well as their excellent adaptability to different environmental conditions. In addition, the cultivation of microalgae does not require large areas of arable land [1,2].

The separation of algal biomass is particularly challenging because of the small size and low density of algae, as well as the large volumes of water necessary for algal recovery [3, 4].

Filtration using low-pressure membranes has been highlighted as an excellent separation process given its facile operation, low energy input, and high filtering efficiency without the need for additional chemical contaminants to the system $[4,5]$.

Ceramic membranes have several advantages that enable their use in separation processes and are produced from value-added synthetic materials, such as zirconia, alumina, titania, and silica [6]. The production of porous ceramic membranes by incorporating natural raw materials with competitive prices, combined with highly efficient production processes, can help increase the use of these membranes worldwide [7]. The synthesis of porous ceramics frequently includes a substance which disappears during the thermal treatment of sintering generating an additional network of pores that modify the membrane pore size distribution that could be obtained with the ceramic composition by itself [8].

Therefore, the thermally treated of the clay can be an alternative in the development of membranes. Interactions between the raw materials present in the green body and between the constitutive minerals can be affected by any change in the thermal treatment [9].

Considering the potentials benefits of previous works, this study aimed to develop tubular ceramic membranes by using thermally treated clay (TC) - raw clay (NC) mixture with organic additives such as pore-generating agents. The fabricated membranes were applied to crossflow microfiltration for the recovery of Acutodesmus obliquus. The efficiency of the membranes was evaluated in terms of the mechanical strength, microalgae retention and permeate flow.

\section{MATERIALS E METHODS}

\subsection{Materials}

A commercial composition of faience clay obtained from Cermassas-Pastacer Ltda. (Campo Largo/PR) was used to produce the ceramic membranes applied in this study. This clay was obtained in two forms: raw clay (NC) and thermal treatment clay (TC), which was obtained by exposing the NC to a temperature of $500^{\circ} \mathrm{C}$ for $24 \mathrm{~h}$ with subsequent slow cooling. To form pores in the ceramic membrane, commercial cationic manioc starch (CMS) (Superion 300, with a degree of substitution of $0.033 \mathrm{~mol} / \mathrm{mol}$ to $0.036 \mathrm{~mol} / \mathrm{mol}$ ) was added to the clay mixtures. The CMS was obtained from Grupo Horizonte-Agrícola Horizonte Ltda. PR (Brazil).

The commercial clay was oven dried for $12 \mathrm{~h}$ and ground. The clay NC and TC samples were each crushed in a bench ball mill (TECNAL) with alumina balls and stored for $4 \mathrm{~h}$. Each of the clay samples was passed through a sieve with \#60 Tyler/mesh $(0.250 \mathrm{~mm})$. The TC and NC mixtures in different fractions were named BC. Then, different CMS fractions (SF) varying from 12.3 to $22.5 \%$ were mixed with the $\mathrm{BC}$ and homogenized with water to form a paste with an initial moisture content of $25 \%$. The membranes were then formed via extrusion. The membranes were then sintered at temperature between 872 and $1150^{\circ} \mathrm{C}$ for $30 \mathrm{~min}$. Table 1 shows the experiments with different compositions of BC, $\mathrm{SF}$ and temperature. 
Table 1: Experimental matrix.

\begin{tabular}{l|c|c|c|c|c|c|c|c|c}
\hline Exp & 1 & 2 & 3 & 4 & 5 & 6 & 7 & 8 & 9 \\
\hline BC & 30 & 30 & 70 & 70 & 23 & 77 & 50 & 50 & 50 \\
\hline $\mathrm{SF}$ & 15 & 15 & 15 & 15 & 22.5 & 22.5 & 12.3 & 22.5 & 22.5 \\
\hline $\mathrm{T}$ & 1000 & 1150 & 1000 & 1150 & 1075 & 1075 & 1075 & 872 & 1075 \\
\hline
\end{tabular}

BC: TC fraction in NC (\%); SF: CMS fractions (\%); T: sintering Temperature $\left({ }^{\circ} \mathrm{C}\right)$

The obtained membranes had a tubular shape with an outside diameter of $18.85 \mathrm{~mm}$, inside diameter of $10.75 \mathrm{~mm}$, thickness of $4.05 \mathrm{~mm}$, and length of $200 \mathrm{~mm}$, as shown in Figure 1.

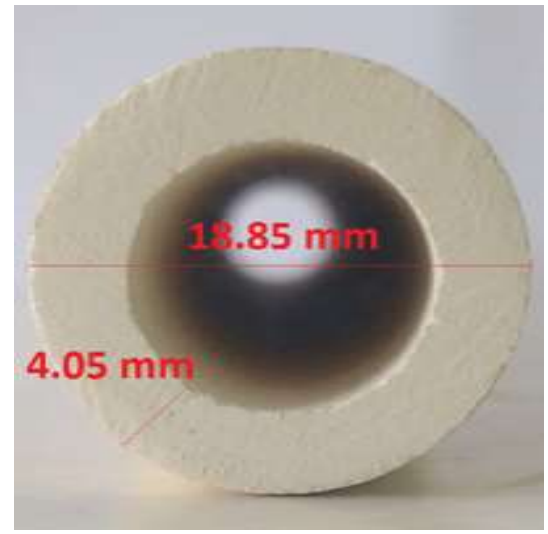

Figure 1: Membrane dimensions.

\subsection{Characterization of clays and membranes}

The ceramic membranes were characterized using a variety of techniques as follows:

$\mathrm{X}$-ray fluorescence $(\mathrm{XRF})$ tests were performed to quantitatively determine the chemical composition of the samples. The tests were conducted using PANalytical equipment (Axios Max) equipped with a rhodium X-ray tube at $4 \mathrm{kv}$. The loss of ignition of the samples was determined by calcination at $1000^{\circ} \mathrm{C}$ for $2 \mathrm{~h}$.

$\mathrm{X}$-ray diffraction (XRD) experiments were performed to identify the glass and mineral phases in the samples. The tests were conducted on PANalytical equipment EMPYREAN with X'Celerator detector and copper tube at a $2 \theta$ range of $3.5^{\circ}$ to $70^{\circ}$. X'Pert High Score Plus was used to interpret the results of XRD analysis. SD, XRF, and XRD analyses were performed in the Laboratory of Analysis of Minerals and Rocks at the Federal University of Paraná (UFPR).

Scanning electron microscopy (SEM) with a $10-\mathrm{kV}$ beam voltage was used to estimate the particle sizes and morphologies of samples (Tescan, LMU; model, Vega 3). The imaging was performed at the Center for Electronic Microscopy, UFPR.

The pore size distributions and densities of the green and sintered samples were determined using AutoPore IV 9500 V1.07 (Micromeritics Instrument Corporation).

The standard three-point bending test was performed to examine the maximum load that could be supported by the membranes. EMIC-DL 30000, a universal test machine, was used with a maximum load capacity of $300 \mathrm{kN}$ and a constant speed of $5 \mathrm{~mm} \cdot \mathrm{min}^{-1}$. The distance between the support points was $90 \mathrm{~mm}$. The mechanical strength of the membrane was determined in accordance with Equation (1)[6]:

$$
\sigma=\frac{8 F L d_{\text {out }}}{\pi\left(d^{4}{ }_{\text {out }}-d^{4}{ }_{\text {in }}\right)}
$$


where $\sigma$ is the mechanical strength of the membrane $(\mathrm{MPa}) ; \mathrm{F}$ is the applied force $(\mathrm{N})$; $\mathrm{L}$ is the distance between the sample support points $(\mathrm{mm})$; and $d_{\text {in }}$ and $d_{\text {out }}$ are the inner and outer diameters of the membrane $(\mathrm{mm})$, respectively.

\subsection{Microfiltration with ceramic membranes}

Filtration experiments were conducted to compare the efficiencies of the membranes in terms of the water permeability under the following operating parameters: a volumetric flow rate of $250 \mathrm{~L} \cdot \mathrm{h}^{-1}$, pressure of $1.0 \mathrm{bar}$, and a temperature of $10 \pm 5^{\circ} \mathrm{C}$. The benchtop scale filtration system comprised a feed tank, a pump for fluid circulation, and a membrane module (Fig. 2).

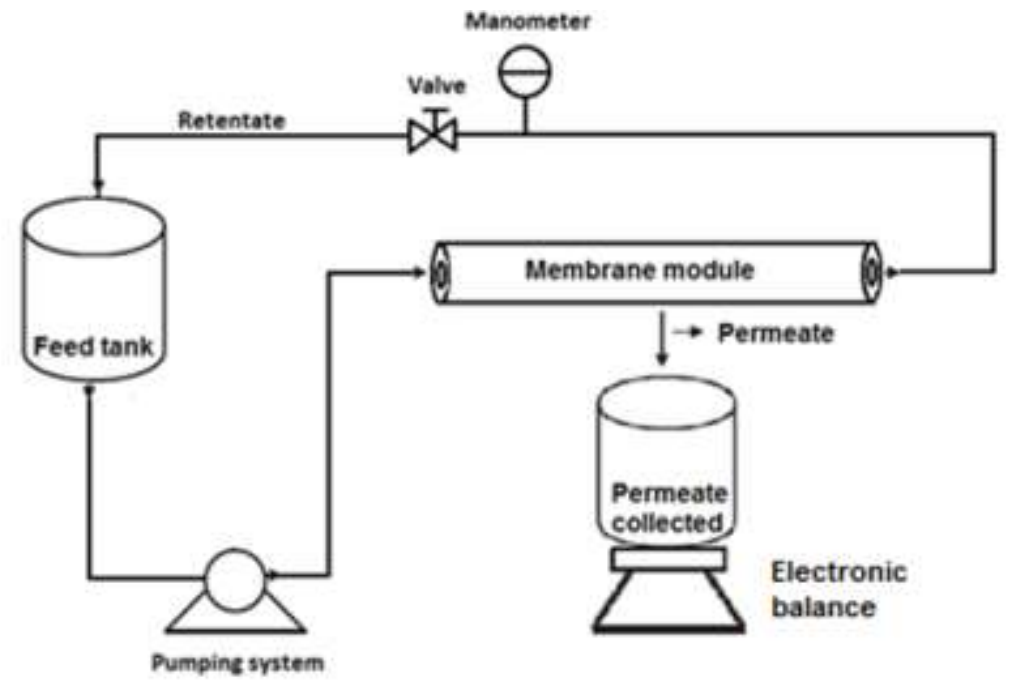

Figure 2: Benchtop-scale microfiltration system used in this study.

Prior to flow measurements, each membrane was characterized and then compacted with water under a constant flow rate of $250 \mathrm{~L} \cdot \mathrm{h}^{-1}$ and pressure of $1.0 \mathrm{bar}$ for $45 \mathrm{~min}$. At the end of each experiment, the membranes and filtration unit were chemically cleaned with sodium hypochlorite solution (1000 ppm) [10]. The water tests were repeated to verify that the membrane and filtration system were effectively cleaned.

After compaction, microfiltration tests were conducted with a constant flow rate of $250 \mathrm{~L} \cdot \mathrm{h}-1$ and pressure of 1.0 bar. In each test, permeate samples were collected every 4 min to determine the retention efficiency of the membranes.

\subsection{Measurement of water flow through the ceramic membrane}

The permeate flow, $\mathrm{J}\left(\mathrm{kg} \cdot \mathrm{m}^{-2} \cdot \mathrm{h}^{-1}\right)$, was determined according to the following equation.

$$
J=\frac{m_{p}}{A_{p} \cdot t}
$$

where $m_{p}$ is the mass of the permeate $(\mathrm{kg}), \mathrm{A}_{\mathrm{p}}$ is the membrane area $\left(\mathrm{m}^{2}\right)$, and $\mathrm{t}$ is the operating time $(\mathrm{h})$. The hydraulic permeability, $\mathrm{Lp}\left(\mathrm{kg} \cdot \mathrm{m}^{-2} \cdot \mathrm{h}^{-1} \cdot \mathrm{bar}^{-1}\right)$, was determined according to Eq. (3) [6, 11].

$$
J=L_{p} \Delta P
$$

where $\mathrm{J}$ is water permeate flow versus the transmembrane pressure, $\Delta \mathrm{P}$ (bar).

The percent of turbidity removal, TR, can be calculated using the following equation [12]: 


$$
T R(\%)=\frac{T_{0}-T_{f}}{T_{0}} \times 100
$$

\subsection{Application of ceramic membranes to retain microalgae}

An A. obliquus strain was isolated by the Nucleus of Self-sustaining Energy Research and Development in Curitiba. The alga was cultivated in a tubular photobioreactor using a photoautotrophic technique involving water and $2.5 \%(\mathrm{v} / \mathrm{v})$ biodigested swine wastewater effluent as the culture medium. Cultures were maintained at ambient temperature and irradiation conditions and supplied with compressed air comprising $0.04 \%(\mathrm{v} / \mathrm{v}) \mathrm{CO}_{2}$. For use in the experiments, fresh cultures were taken from the photobioreactor at day 15 during the exponential growth phase (cell density: $2.54 \times 10^{13}$ cells $\cdot \mathrm{m}^{-3}$; cell concentration: $0.60 \mathrm{~kg} \cdot \mathrm{m}^{-3}$ ) [7].

Filtration experiments were conducted with the membranes to compare the effects of BC, SF and sintering temperature. The tests were conducted at pressures of 1 bar. Tests for each set of conditions were performed in triplicate with a new membrane for each trial. The operating temperature was $10 \pm$ $5^{\circ} \mathrm{C}$. Then, the permeate flow, hydraulic permeability and retention of the microalgae suspension were calculated using Eqs. 2, 3 and 4, respectively.

\section{RESULTS AND DISCUSSION}

Characterizations of clays (NC and TC) using techniques of Granulometric analysis, Scanning electron microscopy (SEM), Thermogravimetric analysis (TGA) are reported in Henriques et al 2017 [7].

\subsection{Results for mechanical strength}

The membranes were characterized according to their mechanical strength to determine the maximum load that they can support. The mechanical strength of each membrane was calculated according to Eq. (1). The average results mechanical strengths are presented in Figure 3.

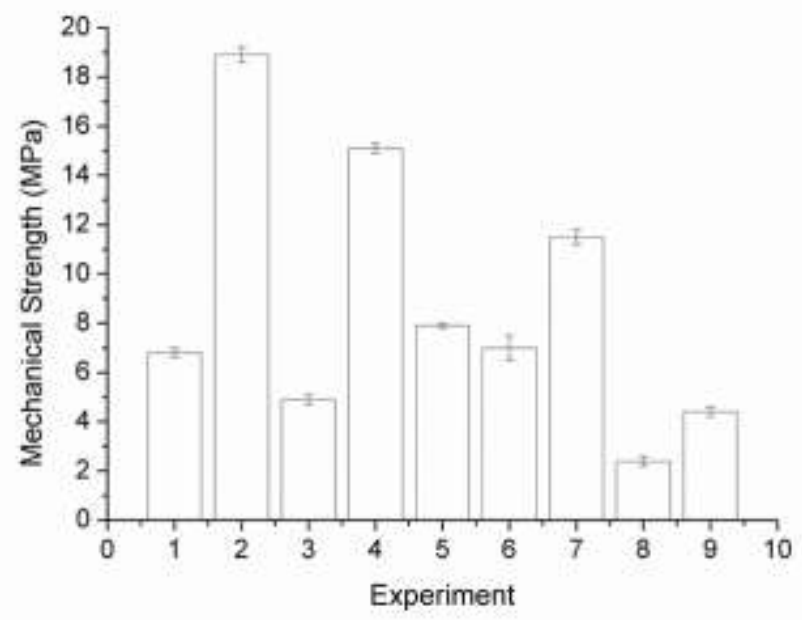

Figure 3: Mechanical strengths of the membranes.

The results indicate a significant difference between the membranes in terms of the mechanical strength. As shown in Figure 3, the obtained mechanical strength varied from $2.4 \pm 0.2$ to $18.9 \pm 0.3 \mathrm{MPa}$. Experiment 4 has a higher mechanical strength than experiment 3; this difference was related to the sintering temperature, which was higher for experiment $4\left(1150^{\circ} \mathrm{C}\right)$ than for experiment $3\left(1000^{\circ} \mathrm{C}\right)$, for the same $\mathrm{BC}(70 \%)$ and SF (15\%). The comparison of the mechanical strength of experiments 2 and 4 verified that the increase in the $\mathrm{BC}$ of $30 \%$ for $70 \%$ decreased the mechanical strength of $18.9 \pm 0.3$ for

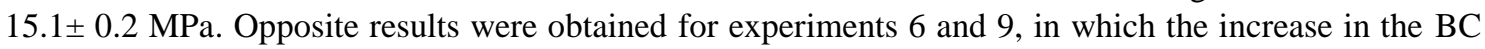
of $50 \%$ for $77 \%$ increased mechanical strength of $4.4 \pm 0.2$ for $7.0 \pm 0.5 \mathrm{MPa}$. The higher sintering temperature may be related to higher mechanical strength. This suggests that higher temperature enhances the mechanical strength. The maximum mechanical strength was obtained in experiment 2 (BC of 30\%, 
SF of $15 \%$ and temperature of $\left.1150^{\circ} \mathrm{C}\right)$.

\subsection{Permeate flow and hydraulic permeability}

The average results permeate flow and hydraulic permeability are presented in Figure 4.

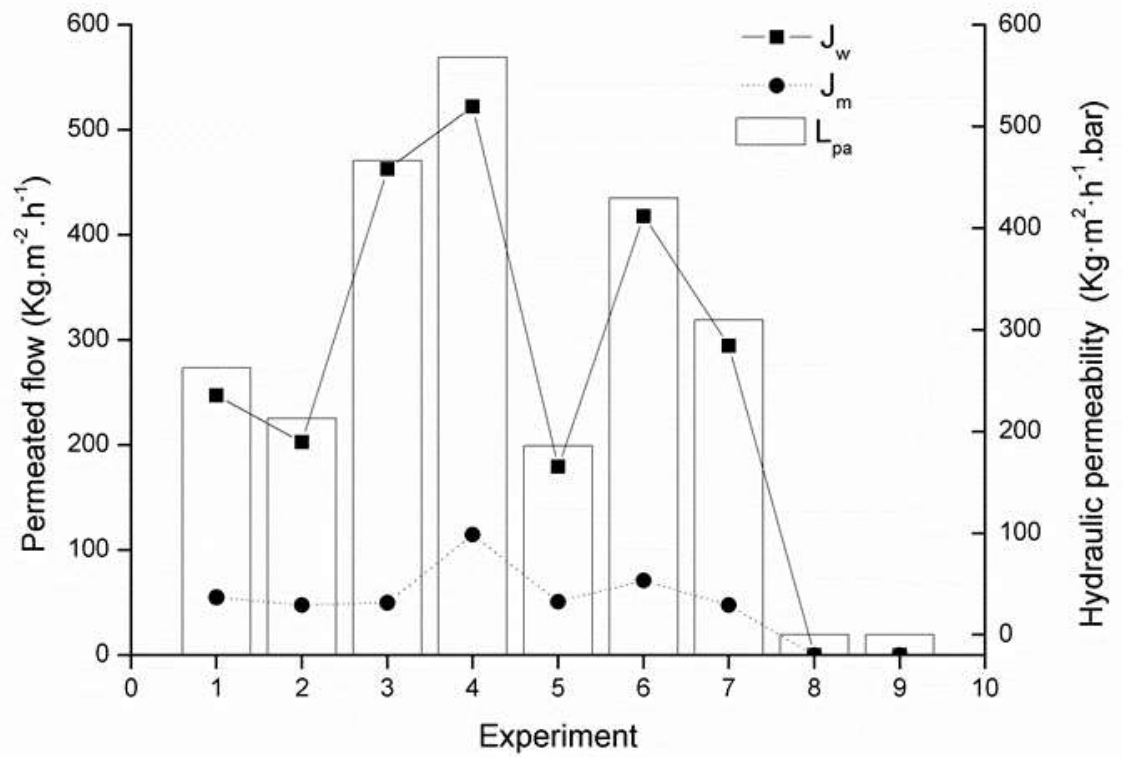

Figure 4: Permeated flow and hydraulic permeability of the experiments. $\mathrm{J}_{\mathrm{w}^{-}}$water permeate flow; $\mathrm{J}_{\mathrm{m}^{-}}$microalgae permeate flow; $\mathrm{L}_{\mathrm{pa}^{-}}$hydraulic permeability

As shown in Figure 4, experiments 4 and 3 had the highest water permeate flow of $522.4 \pm 0.3$ and $462.6 \pm 0.5 \mathrm{Kg} \cdot \mathrm{m}^{-2} \cdot \mathrm{h}^{-1}$, respectively. During microalgae microfiltration, a maximum flow of $114.8 \pm 0.8 \mathrm{Kg} \cdot \mathrm{m}^{-2} \cdot \mathrm{h}^{-1}$ was reached with the experiment 4 , and a flow of $49.9 \pm 0.7 \mathrm{Kg} \cdot \mathrm{m}^{-2} \cdot \mathrm{h}^{-1}$ was found with the experiment 3. Although the two experiments (3 and 4) exhibited good water filtration performance, the mechanical strength of experiment 4 was almost triple the experiment 3 . The superior filtering characteristics of the experiment 4 compared with the experiment 3 can be explained by the structural changes related to higher sintering temperature and higher BC.

The comparison of the experiments 2 and 4 verified that the increase in the BC of $30 \%$ for $70 \%$ increased the water permeate flow of $202.9 \pm 0.7$ for $522.4 \pm 0.3 \mathrm{Kg} \cdot \mathrm{m}^{-2} \cdot \mathrm{h}^{-1}$ and microalgae permeate flow of $47.7 \pm 0.2$ for $114.8 \pm 0.8 \mathrm{Kg} \cdot \mathrm{m}^{-2} \cdot \mathrm{h}^{-1}$. These responses indicated that $\mathrm{TC}$ strongly influenced the microfiltration process. These results are within the range of values reported by other authors in literature $[4,13,14]$. These experiments (1-7) exhibited a retention above 99.5\%. TR was calculated using Eq. (4).

Compared with other experiments, experiment 8 was sintered at a low temperature $\left(872{ }^{\circ} \mathrm{C}\right)$. This membrane did not withstand the filtration process and even broke. Although the membrane in experiment 9 was sintered at $1075^{\circ} \mathrm{C}$, it also ruptured during filtration.

Henriques et al. 2017 [7], previously have verified that membranes containing only TC possess higher hydraulic permeability and permeate flow values than those containing only NC. However, TC membranes have low mechanical strength $(4.34 \mathrm{MPa})$. Thus, it can be proved that the TC-NC mixture significantly increases mechanical strength without compromising the filtering characteristics.

To verify the reason for the increase in mechanical strength, XRF, XRD and SEM analysis of the experiments 2, 3, 4, 6 and 9 were evaluated. 


\subsection{XRF analysis}

The quantitative compositions of the clay and experiments as oxide were determined by XRF analysis and are presented in Figure 5.

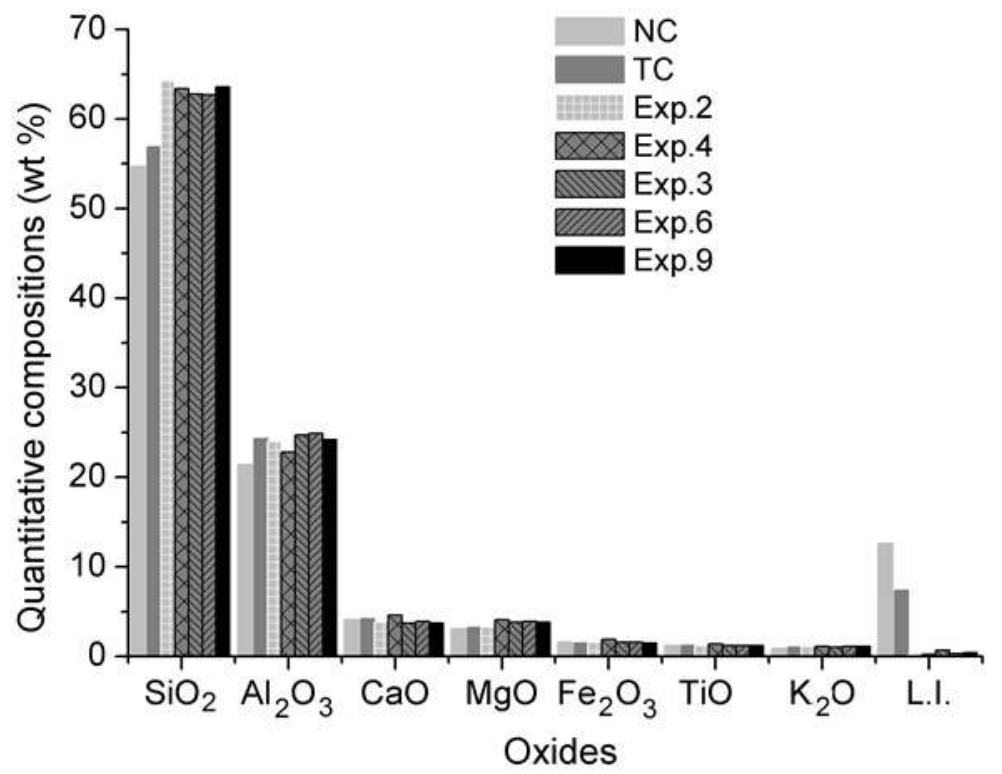

Figure 5: Quantitative compositions of the clays and experiments.

Figure 5 shows that the clays and experiments 2, 3, 4, 6, and 9 were mainly composed of $\mathrm{SiO}_{2}$ and $\mathrm{Al}_{2} \mathrm{O}_{3}$, as well as other oxides in small amounts. These oxides are characteristic components of clay minerals. The loss on ignition at $1000{ }^{\circ} \mathrm{C}$ during $2 \mathrm{~h}$ was due to the loss of water and organic matter, compared with other experiments, experiment 3 had the highest loss on ignition. This loss may be due to higher $\mathrm{NC}$ in its composition. The compositions of $\mathrm{CaO}(4.6 \mathrm{wt} \%)$ and $\mathrm{MgO}(4.1 \mathrm{wt} \%)$ in experiment 4 were higher than those in other experiments (experiments 2, 3, 6, and 9).

\subsection{XRD analysis}

The clays and membranes were analyzed by XRD to identify the crystalline and amorphous phases. The XRD patterns of NC and TC (Figure 6) contain more expressive crystalline reflections that indicate quartz, Kaolinite, Calcite, Dolomite, Talc and Anatase, in addition to the alkali feldspar phase that is identified only in the TC sample. 


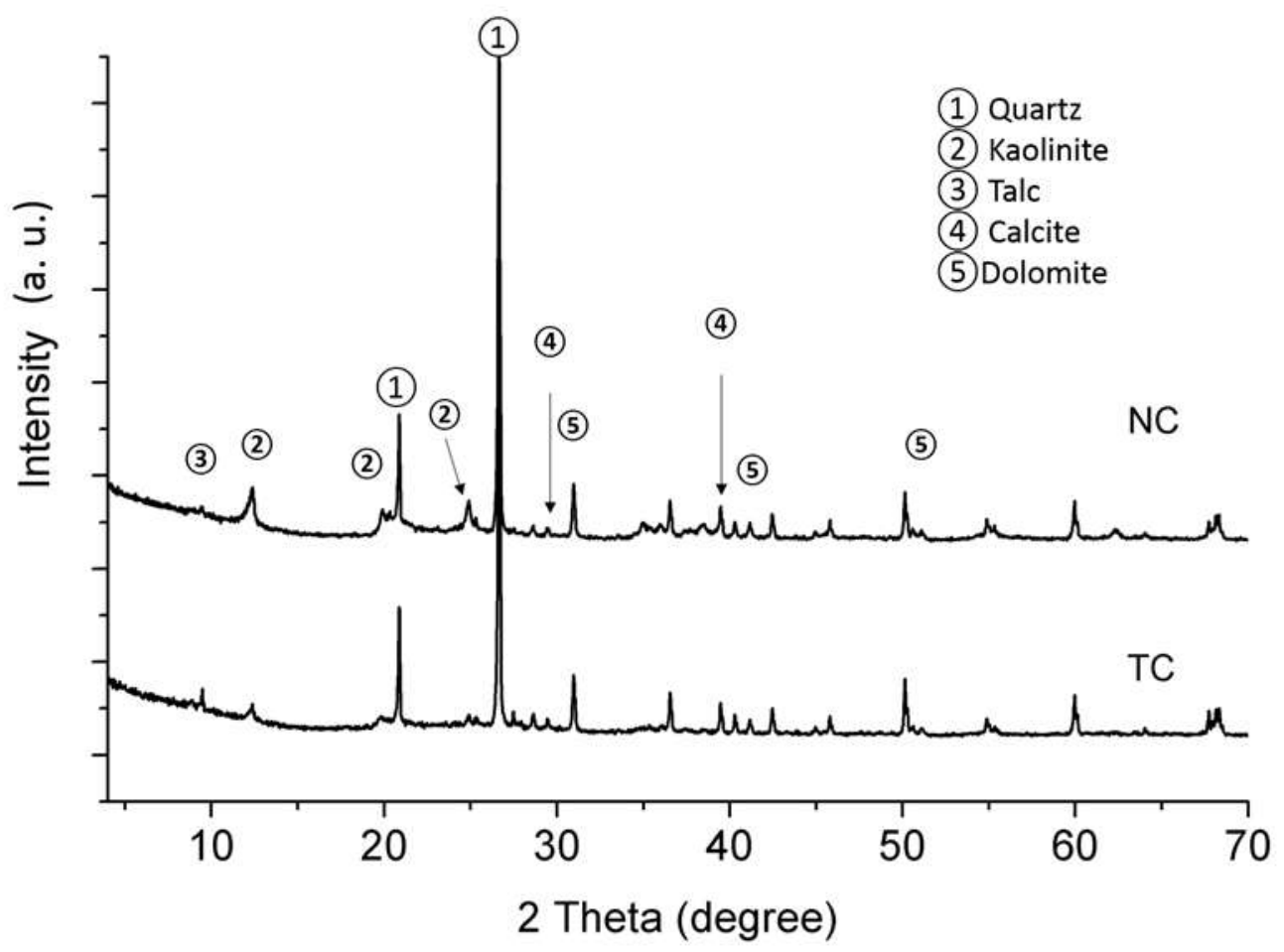

Figure 6: XRD patterns of NC and TC.

The thermal treatment in $\mathrm{NC}$ provided a possible phase change of kaolinite $\left(\mathrm{Al}_{2} \mathrm{Si}_{2} \mathrm{O}_{5}(\mathrm{OH})_{4}\right)$ in metakaolinite, observed as a decrease in the reflection intensity related to kaolinite (Figure 6). The diffraction peaks of Kaolinite become less intense, thus indicating the progress of the dihydroxylation reaction and, consequently, the kaolinite is transformed into amorphous metakaolinite [15].

The XRD patterns of experiments 2, 3, 4, 6 e 9 (Figure 7) contain more expressive crystalline reflections that indicate mullite, albite and quartz, in addition to the cristobalite phase that is identified only in the experiments 2 and 4 . 


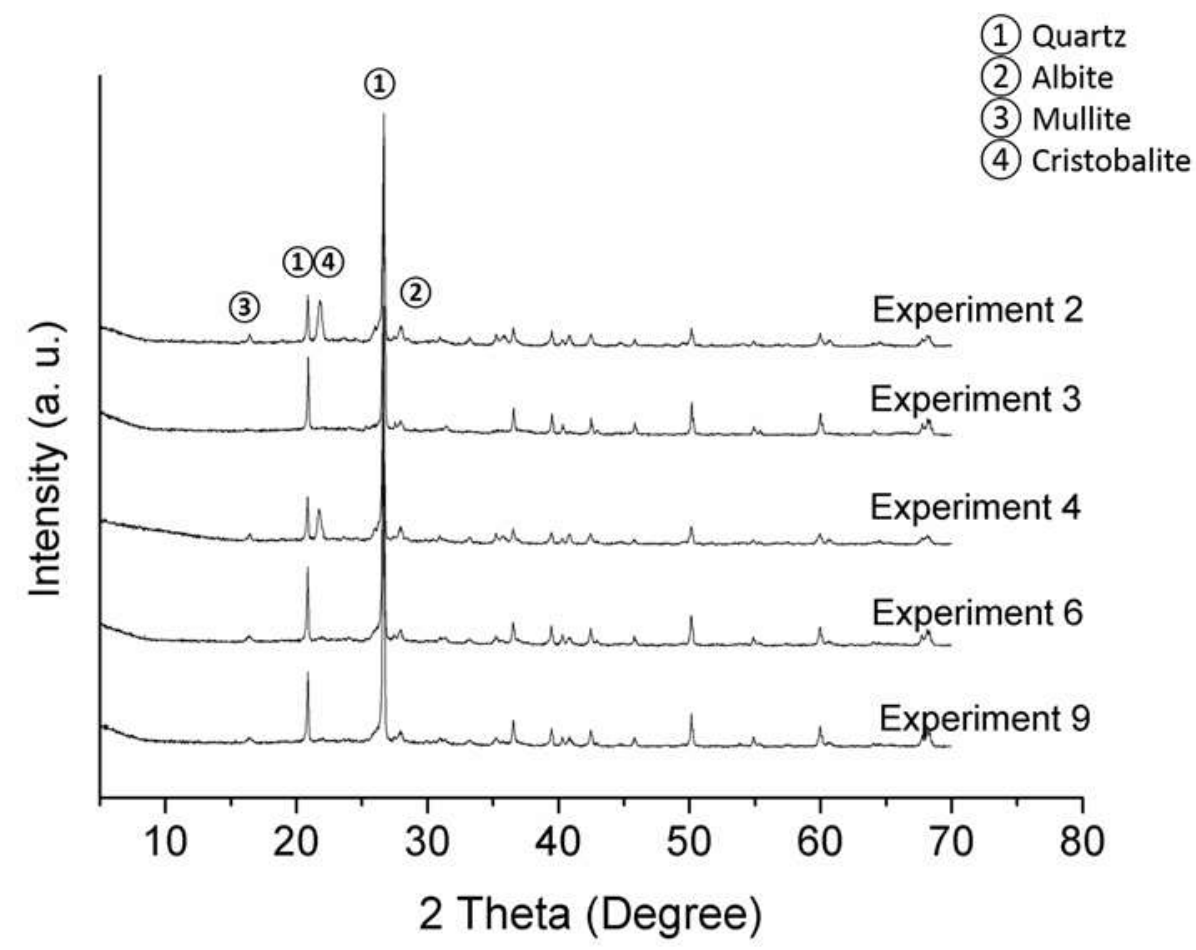

Figure 7: XRD patterns of the experiments 2, 3, 4, 6 e 9.

The higher mechanical strength of the experiments 2 and 4 was possibly due to the sintering temperature, providing similarity in many of their reflections coinciding. The onset crystallization temperature of cristobalite was near $1150^{\circ} \mathrm{C}$. Tao et al [16], obtained the onset crystallization temperature of cristobalite near of $1100^{\circ} \mathrm{C}$, and the peak intensity of cristobalite became higher as calcination temperature increased. The decrease in the reflection intensity was slightly greater for experiment 2 than that for experiment 4 , indicating more disruption of the crystalline structure that may be associated the metakaolinite. The XRD results for experiments 3, 6, and 9 were strongly similar, with a large part of their peaks coinciding. The experiment 3 had a lower incidence of mullite phase, due to the sintering temperature $\left(1000^{\circ} \mathrm{C}\right)$.

\subsection{XRD SEM of 2, 3, 4, 6 e 9 experiments}

The morphologies of the clays and the membranes were evaluated by SEM as shown in Figure 8 . The structures of the membranes were characterized by different pore shapes and sizes and a relatively complex pore distribution. 
a)

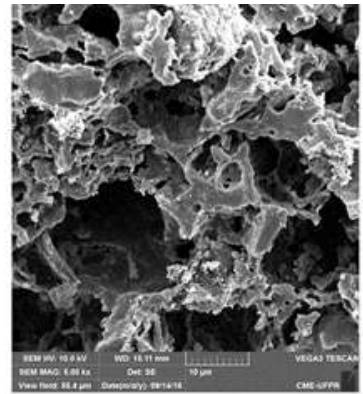

c)

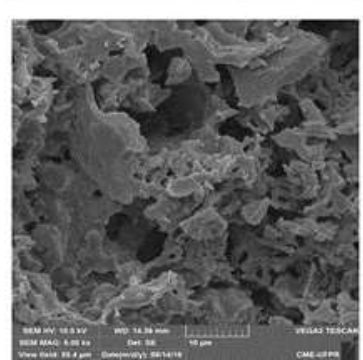

b)

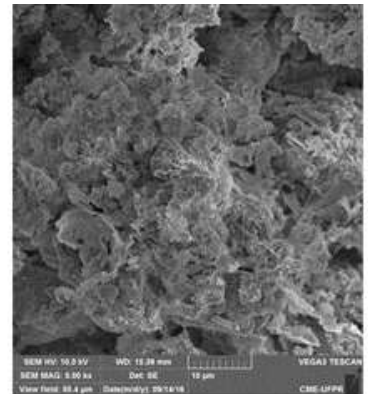

d)

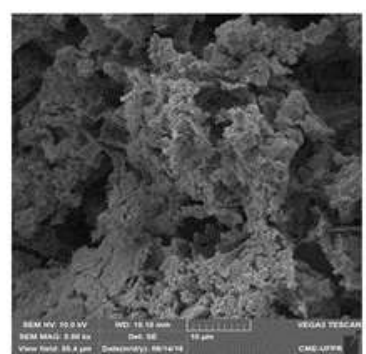

e)

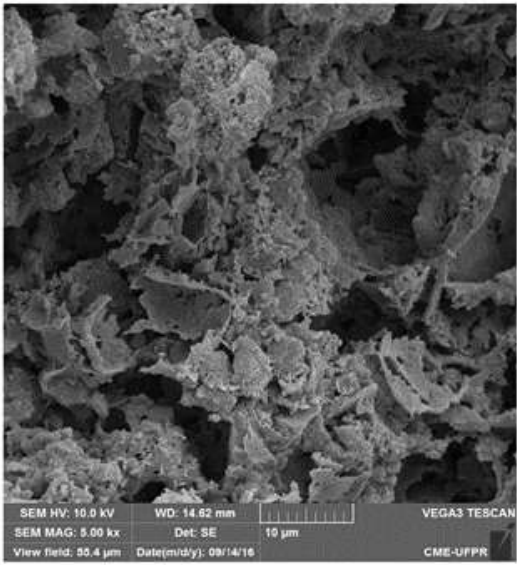

Figure 8: SEM micrographs of a) Experiment 2, b) Experiment 3, c) Experiment 4, d) Experiment 6 and e) Experiment 9 at magnifications of 5000x.

A larger number of pores were seen in the micrographs of the experiments 2 and 4 compared with those of the experiments 3,4,6 and 9. The higher agglomeration of the experiment 2 may be associated with the organic matter contained in the $\mathrm{NC}$, and the greater particle dispersion may have been due to the thermally treatment and temperature applied to the experiments 2 and 4 . These observations suggested that the experiment 4 had a higher porosity and the experiment 2 has a higher mechanical strength.

\subsection{Mercury intrusion method for experiment 4}

Figure 9 shows the cumulative volume as a function of pore size for experiment 4 . There was an initial increase in the cumulative volume followed by a constant region of intrusion. Due to the presence of larger pores, the total pore volume was greater. According Henriques et al. 2017 [7], the cumulative volume was by approximately $45 \%$ with the thermal treatment clay (TC). The mixtures (TC/NC) of the clays caused an increase in the cumulative volume of the membrane by approximately $35 \%$.

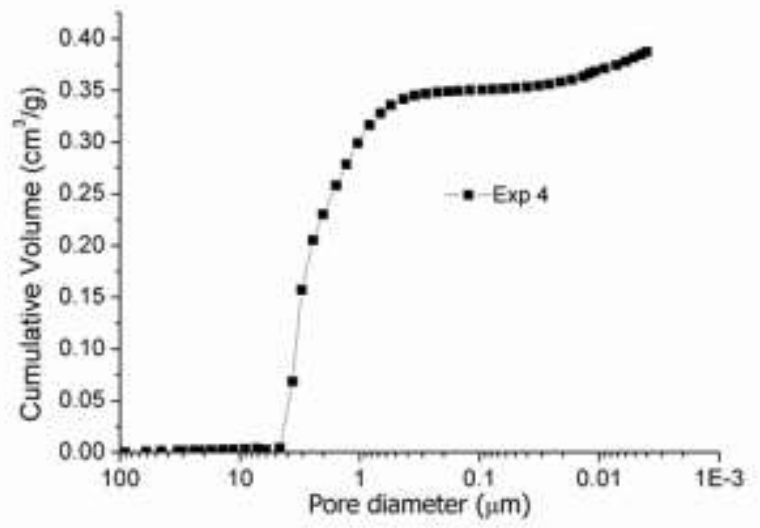

Figure 9: Cumulative volume of experiment 4. 


\section{CONCLUSION}

Tubular ceramic membranes were effectively fabricated by the extrusion of NC- TC mixtures. The results showed that the experiment 4 made with $\mathrm{BC}$ of $70 \%$, SF of $15 \%$ and $1150^{\circ} \mathrm{C}$ had higher water and microalga permeate fluxes and mechanical strength of $15.1 \pm 0.2 \mathrm{MPa}$. The higher sintering temperature may be related to higher mechanical strength. A maximized water permeate flow of $522.4 \pm 0.3 \mathrm{~kg} \cdot \mathrm{m}^{-2} \cdot \mathrm{h}^{-1}$ was obtained. The better filtration performance of the experiment 4 can be explained by the addition of TC observed through several analyses. These results indicate that the experiment 4 may be used to recover A. obliquus microalgae by microfiltration.

\section{ACKNOWLEDGEMENTS}

The authors acknowledge with gratitude the support of the Brazilian National Council of Scientific and Technological Development - CNPq Project 454669/2014-3. They also thank the Federal University of Paraná (UFPR) and Technology Sector from UFPR for infrastructural support. LAMIR and CME of the Federal University of Paraná (UFPR) for analytics support.

\section{BIBLIOGRAPHY}

[1] CHISTI, Y., "Biodiesel from microalgae”, Biotechnology Advances, v. 25, pp. 294-306, May. 2007.

[2] MATA, T. M., MARTINS, A. A., CAETANO, N. S., "Microalgae for biodiesel production and other applications: A review", Renewable and Sustainable Energy Reviews, v. 14, pp. 217-232, Jan. 2010.

[3] BRENNAN, L., OWENDE, P., "Biofuels from microalgae - A review of technologies for production, processing, and extractions of biofuels and co-products", Renewable and Sustainable Energy Reviews, v.14, pp. 557-577, Feb. 2010.

[4] ZHANG, X., HU, Q., SOMMERFELD, M., PURUHITO, E., et al., "Harvesting algal biomass for biofuels using ultrafiltration membranes", Bioresource Technology, v. 101, pp. 5297-5304, Jul. 2010.

[5] ZOU, S., GU, Y., XIAO, D., et al., "The role of physical and chemical parameters on forward osmosis membrane fouling during algae separation", Journal of Membrane Science, v. 366, pp.356-362, Jan. 2011.

[6] KUMAR, R. V., GHOSHAL, A. K., PUGAZHENTHI, G., "Elaboration of novel tubular ceramic membrane from inexpensive raw materials by extrusion method and its performance in microfiltration of synthetic oily wastewater treatment", Journal of Membrane Science, v. 490, pp. 92-102, Sep. 2015.

[7] HENRIQUES, J.D. O., PEDRASSANI, M.W., KLITZKE, W., et al., "Thermal treatment of claybased ceramic membranes for microfiltration of Acutodesmus obliquus", Applied Clay Science, v. 150, pp. 217-224, Dec. 2017.

[8] LORENTE-AYZA, M. M., ORTS, M. J., PÉREZ-HERRANZ, V., et al., "Role of starch characteristics in the properties of low-cost ceramic membranes", Journal of the European Ceramic Society, v.35, pp. 2333-2341, Aug. 2015.

[9] CASTELEIN, O., SOULESTIN, B., BONNET, J.P., et al., "The influence of heating rate on the thermal behaviour and mullite formation from a kaolin raw material", Ceramic International, v. 27, pp. 517-522, 2001.

[10] BILAD, M. R., VANDAMME, D., FOUBERT. I., et al., "Harvesting microalgal biomass using submerged microfiltration membranes", Bioresource Technology, v. 111, pp. 343-352, May. 2012.

[11] NANDI, B.K., UPPALURI, R., PURKAIT, M.K., "Preparation and characterization of low cost ceramic membranes for micro-filtration applications", Applied Clay Science, v. 42, pp. 102-110, Dec. 2008.

[12] BeliBi, P.B., NGUEMTChOUIN, M.M.G., RIVALlin, M., et al., "Microfiltration ceramic membranes from local Cameroonian clay applicable to water treatment", Ceramic International, v. 41, pp. 2752-2759, Oct. 2015.

[13] BHAVE, R., KURITZ, T., POWELL, L., et al., "Membrane-based energy efficient dewatering of microalgae in biofuels production and recovery of value added co-products", Environmental Science \& Technology, v. 46, pp. 5599-5606, Apr. 2012. 
[14] GERARDO, M. L., OATLEY-RADClifFE, D. L., LOVITT, R. W., "Minimizing the Energy Requirement of Dewatering Scenedesmus sp. by Microfiltration: Performance, Costs, and Feasibility", Environmental Science \& Technology, v. 48, pp. 845-853, Dec. 2014.

[15] GASPARINI, E., TARANTINO, S.C., GHIGNA, P., et al., "Thermal dehydroxylation of kaolinite under isothermal conditions", Applied Clay Science, v. 80-81, pp. 417-425, Aug. 2013.

[16] TAO, X., ZHANG, L., MA, X., et al., "Preparation of a flexible high emissivity coating on quartz fiber fabric for thermal protection”, Ceramic International, v. 43, pp. 14292-14300, Nov. 2017.

\section{ORCID}

Julcelly Dayara de Oliveira Henriques

Marina Wendt Pedrassani

Walderson Klitzke

Thamayne Valadares de Oliveira

Patricia Angélica Vieira

André Bellin Mariano

Rafael Bruno Vieira https://orcid.org/0000-0001-9247-5115

https://orcid.org/0000-0003-2860-0609

https://orcid.org/0000-0002-7850-4335

https://orcid.org/0000-0003-0896-6363

https://orcid.org/0000-0003-4549-7500

https://orcid.org/0000-0002-1693-8947

https://orcid.org/0000-0003-2199-1870 